DOI 10.18551/rjoas.2019-04.26

\title{
PLANTING OF RAMIN (GONYSTYLUS BANCANUS KURZ) WILDING IN PEAT SWAMP THICKET OF CENTRAL KALIMANTAN
}

\author{
Rahmawati Reni, Lecturer \\ Department of Forestry, Faculty of Agriculture, University of Palangka Raya, Indonesia \\ E-mail: renirahmawati@for.upr.co.id
}

\begin{abstract}
The purpose of this study was to determine the effect of planting row with different widths on the growth of Ramin seedlings planted in the area of peat swamp thicket. The research design used was Randomized Block Design (RBD) with 3 treatments, namely $L 0=$ planting in a row without a clearance; $L 1=$ planting in a row with a clearance of $1 \mathrm{~m}$ width; L3 = planting in a row with a clearance of $3 \mathrm{~m}$ width each of 3 plots (plot size $30 \times 30 \mathrm{~m}$ ) with a plant spacing of $5 \times 5 \mathrm{~m}$, so that the total number of seeds equal to 324 seeds. The variables measured and observed were the success / percentage of life of Ramin plants, percentage of bud growth and relative growth rate. Observations and measurements are carried out every 2 (two) weeks. The success of the plant life was $72,5 \%$. The success of bud growth $34,9 \%$ and a relatively high growth rate of $11,1 \%$. The bud growth and the relatively high growth rate of the Ramin plant in the peat swamp thicket for six months resulted in the highest growth in the treatment of Ramin planting in the row without clearance compared with planting in the row with the clearance of 1 and 3 meters width.
\end{abstract}

\section{KEY WORDS}

Peat swamp thicket, row, clearance.

Ramin trees thrive in peat swamp natural forests on Sumatra Island, Karimata Strait Islands, and Kalimantan. Ramin wood has high economic value and is categorized as beautiful wood. High selling prices and large market needs for this type make exploitation activities out of control in natural forests (Samojlik et al., 2019; Sen \& Pattanaik, 2019; Nuță, 2019; Mcelwee, 2008; Lambin \& Meyfroidt, 2011). The government's effort in conservation is to include Ramin in Appendix III of CITE (Convention International Trade Endangered Species of Wild Fauna and Flora ) (CITES) Appendix II, in 1994 as an endangered tree. Ramin cultivation has problems, including the recalcitrant seeds, erratic fruiting season, the success rate of growing saplings is still very low and the regeneration process is slow (Bismark et al., 2006; Morrogh-Bernard et al., 2003; Supriana et al., 1978; Van der Meer et al., 2008; Yule, 2010; Smulders et al., 2008; Chua, 2008; Lescuyer et al., 2019; Ogoti, 2019).

Wahyudiningsih \& Rahmawati (2005), Rotinsulu et al. (2007), that various efforts have been made to increase the potential of ramin in peat swamp forests namely by maintaining existing ramin saplings and ramin cultivation which can grow as well as natural ramin growth in peat swamp forests. nformation on the technique of ramin cultivation has been limited, especially for enrichment activities in regenerated empty spaces, how the proper plant techniques and maintenance so that they can spur the growth of seeds in nature. The general growth stimulation carried out in silviculture is maintenance with clearance.

Based on this, it is necessary to strive for planting ramin seedlings in secondary forests/ peat swamp thicket area with the hope of increasing the productivity of peat swamp forests in order to meet the needs of ramin wood by making ramin plant forest.

\section{METHODS OF RESEARCH}

The study was conducted in the peat swamp thicket area of Taruna Village, Pulang Pisau Regency, Central Kalimantan Province, for 10 (ten) months, starting from June 2014 to March 2015. 
The material used in the research is the seed of Ramin (Gonystylus bancanus Kurtz) derived from wilding which had been adapted in the nursery for 3 months as many as 400 seeds. The tools used among other sarlon, polybag, measuring ruler, plastic rope, compass, machete, label paper, hoes, carpentry tools, stationery, etc.

The experimental design used was a Randomized Block Design (RBD) with 3 treatments, each with 3 groups/plots (plot size $30 \times 30 \mathrm{~m}$ ) with a plant spacing of $5 \times 5 \mathrm{~m}$, so that the total number of seeds equal to 324 seeds.

The treatment of this study are:

- $\mathrm{LO}=$ planting in a row without clearance;

- $\quad \mathrm{L} 1=$ planting in a row with a clearance of $1 \mathrm{~m}$ width;

- $\quad \mathrm{L} 3$ = planting in a row with a clearance of $3 \mathrm{~m}$ width.

The variables measured and observed were the success/percentage of life of Ramin plants, percentage of bud growth and relative growth rate.

The procedure/stage of this research are:

- Preparation of Ramin Seeds. Ramin seeds come from wilding that has been adapted in nurseries for 3 months with criteria for the seedling height about $20-60 \mathrm{~cm}$ and have good growth

- Making the Research Plot. The research plot was made in peat swamp thicket with the size $30 \mathrm{~m} \times 30 \mathrm{~m}$ as many as 9 plots with a distance between plots of $2,5 \mathrm{~m}$.

- Making the Planting Row. Make the planting row as wide as $1 \mathrm{~m}$ and $3 \mathrm{~m}$ with the direction of East- West. Planting row must be completely open so that light can enter optimally with a distance between the axes of the planting row equal to $5 \mathrm{~m}$.

- Installation of Ajir and Planting Holes. Ajir is made of wood with a length of approximately $1 \mathrm{~m}$ and the tip is given a red mark. Ajir is installed in planting row with a distance of $5 \mathrm{~m} \times 5 \mathrm{~m}$. On the side of ajir, a planting hole is made and left for 1 week before planting activities are carried out.

- Planting. The planting trial was carried out on August 15th, 2014 - February 15th, 2015 (for 6 months). Observations and measurements are carried out every 2 weeks.

- Ramin Seedling Maintenance. Conduct weeding/clearance activities towards weed plants whose its shade canopy which carried out every 2 weeks.

\section{RESULTS AND DISCUSSION}

Success of Life and Buds Growing of Ramin Plants. Based on the results of measurements and observations of Ramin plants in peat swamp thicket for 6 (six) months, the success/percentage of life and growth of Ramin bud presented in Table 1 below.

Table 1 - Percentage of Life and Bud Growth of Ramin Plants in peat swamp thicket for 6 (six) months

\begin{tabular}{|c|c|c|c|c|c|c|c|}
\hline \multirow{2}{*}{ Clearance Width } & \multirow{2}{*}{ Plot } & \multicolumn{2}{|c|}{ Percentage } & \multicolumn{2}{|c|}{ Percentage } & \multicolumn{2}{|c|}{ Average \% } \\
\hline & & Life & $\%$ & Bud & $\%$ & Life & Bud \\
\hline \multirow{3}{*}{0 meter } & 1 & 30 & 83,3 & 22 & 61,1 & \multirow{3}{*}{80.8} & \multirow{3}{*}{38,9} \\
\hline & 2 & 28 & 77,8 & 12 & 33,3 & & \\
\hline & 3 & 29 & 80,6 & 8 & 22,2 & & \\
\hline \multirow{3}{*}{1 meter } & 1 & 25 & 69,4 & 20 & 55,6 & \multirow{3}{*}{72,2} & \multirow{3}{*}{36,1} \\
\hline & 2 & 27 & 75,0 & 8 & 22,2 & & \\
\hline & 3 & 26 & 72,2 & 11 & 30,6 & & \\
\hline \multirow{3}{*}{3 meter } & 1 & 21 & 58,3 & 12 & 33,3 & \multirow{3}{*}{64,8} & \multirow{3}{*}{29,6} \\
\hline & 2 & 25 & 69,4 & 12 & 33,3 & & \\
\hline & 3 & 24 & 66,7 & 8 & 22,2 & & \\
\hline
\end{tabular}

Based on Table 1 the percentage of Ramin plant life for 6 months is only $72,5 \%$. The causes of death are thought to be related to environmental factors, planting techniques and seeds used. Some field conditions are inundated so that it can cause oxygen deficiency which can damage root development, namely the occurrence of decay in the roots causing death. 
The percentage of the bud growth of Ramin plants in the thicket of peat swamps is decreasing with increasing width of the planting row in the thicket which is 1 meter high with an average seedling height of only $30 \mathrm{~cm}$. With the increase in width of the row, the higher the intensity of the light received by the seed. High light intensity is good for root growth rather than bud growth. According to Soekotjo (1976), Totland (1999), Shah et al. (2011), Vasseur et al. (2011), McDowell et al. (2008), Hatfield \& Prueger (2015), Zandalinas et al. (2018), Jabran \& Doğan (2018), high intensity causes an increase in leaf temperature which has a negative effect on plants, among others, the decline of photosynthesis, excessive transpiration so that the stem becomes shorter, leaves are thicker and smaller, and the occurrence of growth decreases.

Relative Growth Rate of Ramin Plants. Relative Growth Rate based on measurement results of height increment and the number of buds are presented in the following Tables 2 and 3.

Table 2 - The results of variance of relative high growth and the number of buds of Ramin plants in peat swamp thicket for 6 months

\begin{tabular}{ccc}
\hline Source of Variability & High Growth & Number of Bud \\
\hline Planting without clearance & Very significant effect & No effect \\
Planting with 1 m clearance & No effect & No effect \\
Planting with 3 m clearance & No effect & No effect \\
\hline
\end{tabular}

Table 3 - Effect of Ramin planting on relative high increment in peat swamp thicket for 6 months

\begin{tabular}{cc}
\hline Source of Variability & Relative High Increment \\
\hline Planting in a row without clearance & $11,1^{\mathrm{a}}$ \\
planting in a row with a clearance of $1 \mathrm{~m}$ & $4,8^{\mathrm{b}}$ \\
planting in a row with a clearance of $3 \mathrm{~m}$ width & $4,7^{\mathrm{b}}$ \\
\hline
\end{tabular}

Notes: Numbers followed by the same letter in the same column are not significantly different at $5 \%$ level of Duncan test.

Statistically there is a very significant effect from the treatment of planting in the row without clearance which given to the increment of Ramin plant height compared to planting in a clean row 1 and 3 meters width.

By planting in an open thicket (1 m thick height) where the light is directly on the Ramin plant, while the Ramin plant with an average height of only $30 \mathrm{~cm}$ still requires shade. This condition can increase the transpiration rate which exceeds the adsorption capacity and affect the activity of stomata cells and fixation of $\mathrm{CO}_{2}$ from the air, for photosynthesis process become reduced, resulting in inhibition of growth.

According to Rajan et al. (1971), Walker et al. (1996), Poorter (1999), Ludwig et al. (2004), Monsi \& Saeki (2005), Mårell et al. (2018) that light is the most important factor that determines the growth and development of vegetation, plant physiological processes such as photosynthesis, respiration and transpiration (Mirecki \& Teramura, 1984; Darrall, 1989, Collatz et al., 1991; Bragina et al., 2004; Lambers et al., 2008; . With the difference in light intensity will also cause differences in temperature, humidity and photosynthesis and transpiration in plantsExcessive light intensity can damage photosynthetic devices, causing an increase in temperature and which has a negative effect on plants, among others, can cause a decrease in photosynthesis.

\section{CONCLUSION AND RECOMMENDATIONS}

Based on the results of the study it can be concluded that the success of Ramin plants in the peat swamp thicket is included in the good criteria with a plant life percentage of $72,5 \%$, The growth of buds and the relatively high growth rate of the Ramin plant in the peat swamp thicket for six months resulted in the highest growth in the treatment of Ramin planting in the row without clearance compared to planting in the row with a clearance of 1 and 3 meters width. 
This research recommends the need for light shade on seeds and Ramin planting land to maintain moisture, because Ramin is very susceptible to high temperatures and land drought, need to be considered when planting should be conducted at the beginning of the rainy season as well as at the time of clearance should not be done in excess, because it can cause wilt/death of plants, in addition, further research needs to be done for a longer time, as information on silvicultural techniques in the field.

\section{REFERENCES}

1. Bismark, M., Wibowo, A., Kalima, T., \& Sawitri, R. (2006). Current growing stock of Ramin in Indonesia. In Prosiding Workshop Nasional "Alternatif Kebijakan Dalam Pelestarian dan Pemanfaatan Ramin", Bogor (Vol. 22).

2. Bragina, T. V., Ponomareva, Y. V., Drozdova, I. S., \& Grinieva, G. M. (2004). Photosynthesis and dark respiration in leaves of different ages of partly flooded maize seedlings. Russian Journal of Plant Physiology, 51(3), 342-347.

3. Chua, L. S. L. (2008, November). Ramin (Gonystylus bancanus) in Malaysia. In NDF Workshop Case Studies. International Expert Workshop on CITES Non-Detriment Findings Cancún, Quintana Roo, Mexico (pp. 17-22).

4. Collatz, G. J. (1991). Physiological and environmental regulation of stomatal conductance, photosynthesis and transpiration: a model that includes a laminar boundary layer. Agricultural and Forest meteorology, 54(2-4), 107-136.

5. Darrall, N. M. (1989). The effect of air pollutants on physiological processes in plants. Plant, Cell \& Environment, 12(1), 1-30.

6. Hatfield, J. L., \& Prueger, J. H. (2015). Temperature extremes: Effect on plant growth and development. Weather and climate extremes, 10, 4-10.

7. Jabran, K., \& Doğan, M. N. (2018). High carbon dioxide concentration and elevated temperature impact the growth of weeds but do not change the efficacy of glyphosate. Pest management science, 74(3), 766-771.

8. Lambers, H., Chapin III, F. S., \& Pons, T. L. (2008). Plant physiological ecology. Springer Science \& Business Media.

9. Lambin, E. F., \& Meyfroidt, P. (2011). Global land use change, economic globalization, and the looming land scarcity. Proceedings of the National Academy of Sciences, 108(9), 3465-3472.

10. Lescuyer, G., Kakundika, T., Muganguzi Lubala, I., Shabani Ekyamba, I., Tsanga, R., \& Cerutti, P. O. (2019). Are community forests a viable model for the Democratic Republic of Congo?. Ecology and Society, 12(1).

11. Ludwig, F., De Kroon, H., Berendse, F., \& Prins, H. H. (2004). The influence of savanna trees on nutrient, water and light availability and the understorey vegetation. Plant Ecology, 170(1), 93-105.

12. Mårell, A., Hamard, J. P., Pérot, T., Perret, S., \& Korboulewsky, N. (2018). The effect of deer browsing and understory light availability on stump mortality and sprout growth capacity in sessile oak. Forest ecology and management, 430, 134-142.

13. Matiru, V. N., \& Dakora, F. D. (2005). Xylem transport and shoot accumulation of lumichrome, a newly recognized rhizobial signal, alters root respiration, stomatal conductance, leaf transpiration and photosynthetic rates in legumes and cereals. New phytologist, 165(3), 847-855.

14. McDowell, N. (2008). Mechanisms of plant survival and mortality during drought: why do some plants survive while others succumb to drought? New phytologist, 178(4), 719-739.

15. Mcelwee, P. D. (2008). Forest environmental income in Vietnam: household socioeconomic factors influencing forest use. Environmental conservation, 35(2), 147159.

16. Mirecki, R. M., \& Teramura, A. H. (1984). Effects of ultraviolet-B irradiance on soybean: $\mathrm{V}$. The dependence of plant sensitivity on the photosynthetic photon flux density during and after leaf expansion. Plant physiology, 74(3), 475-480. 
17. Monsi, M., \& Saeki, T. (2005). On the factor light in plant communities and its importance for matter production. Annals of botany, 95(3), 549.

18. Morrogh-Bernard, H., Husson, S., Page, S. E., \& Rieley, J. O. (2003). Population status of the Bornean orang-utan (Pongo pygmaeus) in the Sebangau peat swamp forest, Central Kalimantan, Indonesia. Biological Conservation, 110(1), 141-152.

19. NUȚĂ, I. S. (2019). THE CONTRAVENTIONAL FORESTRY PHENOMENON. Annals of the University of Craiova-Agriculture, Montanology, Cadastre Series, 48(2), 109-112.

20. Ogoti, A. K. (2019). The Role of Natural Resources in Civil Wars: The Case of Democratic of Congo.

21. Poorter, L. (1999). Growth responses of 15 rain-forest tree species to a light gradient: the relative importance of morphological and physiological traits. Functional ecology, 13(3), 396-410.

22. Rajan, A. K., Betteridge, B., \& Blackman, G. E. (1971). Interrelationships between the nature of the light source, ambient air temperature, and the vegetative growth of different species within growth cabinets. Annals of Botany, 35(2), 323-343.

23. Rotinsulu, J. M, Sukaryanto, R. Rahmawati, Yudha, C. Pidjath. (2007). Teknik Budidaya Jelutung, Galam, dan Ramin. Jurusan Manajemen Hutan Fakultas Pertanian Universitas Palangka Raya, Palangka Raya.

24. Samojlik, T., Fedotova, A., Niechoda, T., \& Rotherham, I. D. (2019). Culturally modified trees or wasted timber: Different approaches to marked trees in Poland's Białowieża Forest. PloS one, 14(1), e0211025.

25. Sen, A., \& Pattanaik, S. (2019). A paradox of the 'community': contemporary processes of participatory forest conservation in the Sundarban Biosphere Reserve (SBR) region of West Bengal. Environmental Sociology, 5(1), 33-46.

26. Shah, F., Huang, J., Cui, K., Nie, L., Shah, T., Chen, C., \& Wang, K. (2011). Impact of high-temperature stress on rice plant and its traits related to tolerance. The Journal of Agricultural Science, 149(5), 545-556.

27. Smulders, M. J. M., VAN 'T WESTENDE, W. P. C., Diway, B., Esselink, G. D., van Der Meer, P. J., \& KOOPMAN, W. M. (2008). Development of microsatellite markers in Gonystylus bancanus (Ramin) useful for tracing and tracking of wood of this protected species. Molecular Ecology Resources, 8(1), 168-171.

28. Soekotjo (1976). Silvika.Proyek Pembangunan Perguruan Tinggi, IPB. Bogor.

29. Supriana, N., Tarumingkeng, R., Wardojo, S., \& Turngadi, A. (1978). Intensity and rate of ambrosia beetle infestation on ramin (Gonystylus bancanus Kurz). In Forum Sekolah Pasca Sarjana(Vol. 2, No. 1, pp. 1-18).

30. Totland, $\varnothing$. (1999). Effects of temperature on performance and phenotypic selection on plant traits in alpine Ranunculus acris. Oecologia, 120(2), 242-251.

31. Van der Meer, P. J., Kunne, P. L. B., Brunsting, A. M. H., Dibor, L. A., \& Jansen, P. A. (2008). Evidence for scatter-hoarding in a tropical peat swamp forest in Malaysia. Journal of Tropical Forest Science, 20(4), 340-343.

32. Vasseur, F., Pantin, F., \& Vile, D. (2011). Changes in light intensity reveal a major role for carbon balance in Arabidopsis responses to high temperature. Plant, cell \& environment, 34(9), 1563-1576.

33. Wahyudiningsih, T. S dan R. Rahmawati. (2005). Propagasi Stek Ramin (Gonystylus bancanus) dan Anakan Gaharu (Aquilaria malaccensis) Dengan perlakuan Konsentrasi IBA dan IAA. Laporan Penelitian DIK UNPAR.

34. Walker, L. R., Zarin, D. J., Fetcher, N., Myster, R. W., \& Johnson, A. H. (1996). Ecosystem development and plant succession on landslides in the Caribbean. Biotropica, 566-576.

35. Yule, C. M. (2010). Loss of biodiversity and ecosystem functioning in Indo-Malayan peat swamp forests. Biodiversity and Conservation, 19(2), 393-409.

36. Zandalinas, S. I., Mittler, R., Balfagón, D., Arbona, V., \& Gómez-Cadenas, A. (2018). Plant adaptations to the combination of drought and high temperatures. Physiologia plantarum, 162(1), 2-12. 